\title{
The Impact of Socioeconomic Reforms on the Work Incentives in Latvia
}

Paper identifies the impact of the proposed and alternative socioeconomic reforms on changes in work incentives in Latvia. This paper aims at the assessing the role of Personal Income Tax and basic allowance in influencing Marginal Effective Tax Rates assessed using various scenarios of hypothetical policy changes. Results show that the tax reform implemented since 2014 has a relatively weak impact on the work incentives of Latvians.

Keywords: work incentives, marginal tax rate, tax-benefit system, EUROMOD microsimulation model.

Straipsnyje, atsižvelgiant $\mathfrak{i}$ siūlomas ir alternatyvias socialines ir ekonomines reformas, nustatomas poveikis darbo paskatoms Latvijoje. Taikant ịvairius hipotetinius valstybės sprendimų scenarijus siekiama ịvertinti gyventojų pajamų mokesčio ir pagrindinių išmokų poveikị nustatant ribinę taikomų mokesčių normą (RTMN). Rezultatai rodo, kad nuo 2014 iggvendinama mokesčių reforma daro gana silpną poveikị latvių darbo paskatoms.

Raktiniai žodžiai: darbo paskatos, ribinė mokesčių norma, mokesčių ir socialinių išmokų sistema, EUROMOD mikrosimuliacinis modelis.

JEL Classifications: C15/H24/H30.

\section{Introduction}

At the international and national levels, the influence of tax and benefit policy on the individual's decision about how much time to spend working is a determinative aspect in the design of public policies. Understanding the labour supply behaviour is thus crucial for socioeconomic reform to ensure more income distribution and invoke incentives for people to work more and earn more. Using the simulation method - European Union tax-benefit microsimulation model (EUROMOD) - and the European Union Statistics on Income and Living Conditions (EU-SILC) survey microdata, this paper identifies the impact of socioeconomic reforms on changes in work incentives in Latvia. Socioeconomic reforms are the research object that is in the focus of interest in the paper. In particular, this paper aims at the assessing the role of Personal Income Tax (PIT) and basic PIT allowance in influencing Marginal Effective Tax Rates (METRs). Higher rate of labour taxes in existence of non-taxable minimum are expected to lower work incentives of high-income 
individuals, but have little effect on the low-income individuals. In addition, it is expected, that actual system of assistance to the indigent population groups reduces their incentives to work and increase their income. This paper compares the distribution of METRs by deciles of disposable equivalised income under the reforms. Estimates of the impact of selected reforms of taxes and benefits on the work incentives of Latvia's population allow determining the socioeconomic reforms which increase work incentives in the country.

An individual's financial incentive to work will depend on the relationship between hours of paid work and net income, taking into account the financial costs of working and not working (Berger, 2010). 'Net income' is an income after benefits and tax credits that have been added and after direct taxes that have been deducted. Therefore, tax-benefit systems play a primary role in influencing work incentives (Jara, Tumino, 2013).

A distinction is usually made between incentives to work versus not working and incentives to work more for those already in work. Two measures of the incentive to work versus not working are commonly distinguished in the literature:

- The replacement rate is measured by net income out of work divided by net income in work;

- The Participation Tax Rate (PTR), defined as 1 minus the financial gain to work as a proportion of gross earnings. It measures the proportion of gross earnings taken in tax or reduced benefits when starting to work.

Low numbers of both rates mean stronger financial incentives to work; but a value of 1 means that there is no financial reward to working (Adam et al, 2006).

The incentives for those already in work to work harder or earn more is measured by the METRs, i.e. the share of additional income that would be taxed away because of taxes, Social Insurance Contribution (SIC) and benefit withdrawal (Jara, Tumino, 2013). As with the incentive to work versus not working, low numbers mean stronger financial incentives. METRs of zero mean that the individual keeps all of any small change in earnings, and a rate of 1 means that the individual keeps none (Adam et al, 2006).

In this paper, the analysis of work incentives concentrates on the METRs to compare work incentives created by social economic reforms in Latvia. METRs are computed dividing all the population by deciles of the equivalised disposable income distribution, taking into account all the interdependencies between incomes of all members of the household. METRs can be calculated only for those who are already in work and have income, but their METRs depend on incomes of other members of the household, even if they are not employed and have zero earnings. This is explained by the existence of benefits: a variation in earnings not only affects the disposable income of the individual whose earnings change, but also benefit entitlements of other members of the household.

$M E T R=1-\frac{Y_{H H}^{1}-Y_{H H}^{0}}{E_{i}^{1}-E_{i}^{0}}$

In practice, METRs (formula 1) are calculated according to the formula, where the numerator is equal to the increase in the household's disposable income generated by an increase in the individual's earnings in period 1 compared to period 0 , and the denominator is equal to the increase in the earnings of individual $i$ in the corresponding period. 


\section{Literature Review}

In previously published works, e.g. X. Jara, A. Tumino (2013) examine the impact of tax-benefit systems on work incentives for the $27 \mathrm{EU}$ countries and finds that for countries with flat PIT tax rate as Baltic states, the PIT component is usually the most important, while the SIC are the second most important component of the mean METRs. Since means tested benefits are aimed to be received by people of the lowest deciles of the income distribution, the increase in the earnings for the lowest deciles results in the benefit withdrawal, while the benefit component takes the higher values of the METRs for these groups of people.

The changes in average METRs between 2007 and 2010 are analysed for the $27 \mathrm{EU}$ countries for all population under the tax system already in force (Jara, Tumino, 2013). However, this paper divides all population by the deciles of equivalised disposable income, and the distribution of METRs by deciles of disposable equivalised income under the possible PIT reforms is compared.

\section{Methodology}

EUROMOD is a tax-benefit microsimulation model for the European Union that enables researchers and policy analysts to calculate, in a comparable manner, the effects of taxes and benefits on household incomes and work incentives for the population of each EU country and for the EU as a whole (University of Essex, 2014). Using the model, individual and household tax liabilities and benefits entitlements are simulated under the existing policy rules in Member State and in Latvia in particular. The instruments usually used in microsimulations at all EU-27 Member States levels are PIT (state and municipal), Social Security Contribution, household benefits, housing benefits, social assistance and other income-related benefits.

Along with calculating the effects of actual policies, EUROMOD is also used to evaluate the effects of tax-benefit policy reforms on changes of poverty rates, income inequality, work incentives and government budgets (University of Essex, 2014) and to simulate the effects of proposed, alternative or hypothetical policy changes, as well as for exploring the implications of alternative economic or demographic scenarios at national and EU levels (Sutherland, Figari, 2013).

The results presented in this report are derived using EUROMOD version F6.36+.

\section{Input data}

Most of EUROMOD input data are derived from the EU-SILC data as released by Eurostat. In some Member States, the national version of SILC - provided by national statistics institutes - is used directly or to complement the EU version due to the availability of more detailed variables (Sutherland, Figari, 2013). Central Statistical Bureau of Latvia provides the access to EU-SILC data. The EUROMOD input database contains information at the individual level on household demographic, labour market characteristics, gross market income and all the other income sources (i.e. pensions, public transfers and private incomes) (Sutherland, Figari, 2013).

Calculations are based on EU-SILC 2010 data (2009 year incomes). The data is not adjusted for labour market and demographic changes that took place over this 
period, therefore the changes in METRs between scenarios reflect the changes in tax-benefit systems, controlling for changes in METRs that occurred because of changes in economic situation or composition of the population.

\section{Implemented Reform: has the Tax Reform Implemented since January 2014 Affected the Work Incentives?}

The baseline tax system of 2013 [1.a.] used in the analysis of METRs includes policy changes that were introduced after June 30, 2013. PIT rate is $24 \%$, the rate of SIC paid by employees rate is $11 \%$, the rate of SIC paid by employers is $24.09 \%$, non-taxable allowance for dependents is EUR 114 (LVL 80) (before June 30, 2013 EUR 100 (LVL
70)), non-taxable minimum is EUR 64 (LVL 45).

In 2013, Ministry of Finance of Latvia proposed several PIT reforms, including increased PIT allowances and decreased SIC rates that came into force since January 2014 [1.b.]. Comparing with the baseline tax system of 2013, PIT is still $24 \%$, the rates for SIC paid by employees and employers are both reduced by 0.5 percentage points to $10.5 \%$ and $23.59 \%$ respectively, non-taxable allowance for dependents increased up to EUR 165 (LVL 116), non-taxable minimum increased up to EUR 75 (LVL 53).

Fig. 1 shows that tax reform affected mainly METRs of the four lowest deciles, while METRs of higher income earners stayed virtually unaffected by the change in the tax system. The mean METR for the lowest decile decreased from 57.9 to 55.6 that are mainly affected by the decrease
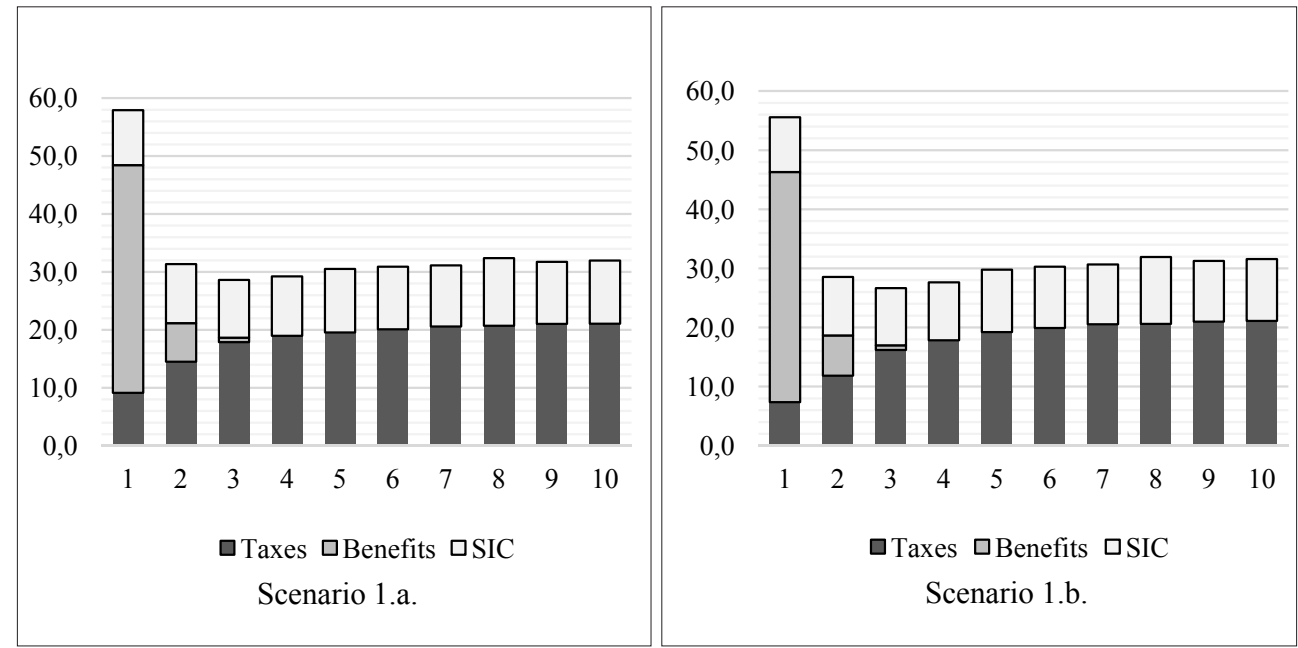

Fig. 1. Mean METRs and contribution of taxes, benefits and SICs by deciles of equivalised disposable income in Latvia under actually observed tax-benefit systems in 2013 and 2014

Note: [1] [1.a.] and [1.b.] tax systems correspond to actually observed tax-benefit system in 2013 and 2014 respectively; [2] The data is not adjusted for labour market and demographic changes that took place over this period, therefore the changes in METRs between scenarios reflect the changes in tax-benefit systems, controlling for changes in METRs that occurred because of changes in economic situation or composition of the population.

Source: authors' calculations based on EU-SILC 2010 data. 
of contribution of taxes to mean METR. The main reason for these changes - the gain from the increased PIT allowances (i.e. non-taxable minimum for dependents and non-taxable minimum) is higher for those with low incomes, as for them the PIT allowances accounts for a bigger share of income. On a whole, the mean METR has decreased from 32.7 to 31.7 that is small but positive effect of the tax reform on the work incentives of Latvians controlling for changes in METRs that occurred because of changes in economic situation or composition of the population.

\section{PIT Reform and Progressive PIT}

The tax system of 2014 that in force since January 2014 [1.b.] is used as a baseline in the analysis of changes in METRs by deciles affected by the changes in the PIT rate applied.

According to the suggestion of Ministry of Finance of Latvia (Ministry of Finance, 2013), PIT is intended to be reduced from the rate of $24 \%$ in 2014 to the rate of $22 \%$ in 2016. The [1.c.] scenario is based on the tax system of 2014 with the reduced PIT rate from $24 \%$ to $22 \%$.

Decreasing PIT rate by 2 percentage points from $24 \%$ to $22 \%$ virtually did not affect mean METR of the lowest decile (see Fig. 2). The main reason for it - since the reduced PIT rate is applied to every income earner according the same statutory rules, the gain from a reduced rate is larger for those with higher income, and is smaller for those with low incomes, as for them the basic tax allowance accounts for a bigger share of income. This makes

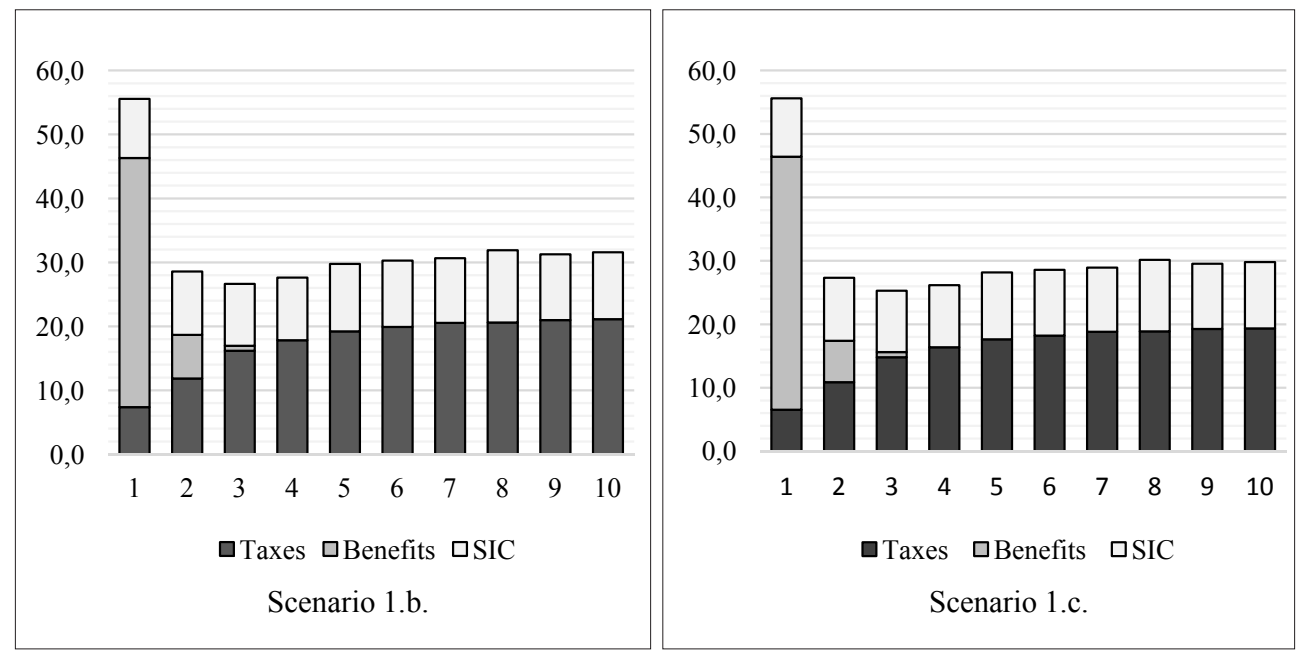

Fig. 2. Mean METRs and contribution of taxes, benefits and SICs by deciles of equivalised disposable income

Note: [1] The tax system of 2014 that in force since January 2014 [1.b.] is used as a baseline in the analysis. [2] The data is not adjusted for labour market and demographic changes that took place over this period, therefore the changes in METRs between scenarios reflect the changes in tax-benefit systems, controlling for changes in METRs that occurred because of changes in economic situation or composition of the population.

Source: authors' calculations based on EU-SILC 2010 data. 
necessary to search for additional solutions that will influence earners with lower income more than earnings of more productive employees.

The following tax reforms make PIT progressive. A higher tax rate for highincome earners is introduced, while the standard tax rate is reduced.

The income level that is taxed at the top PIT rate is set according to the practice of EU Member states. In 2013, 20 out of 27 Member States applied progressive PIT. Two tax bands besides the basic allowance were applied in Czech Republic, Ireland, Poland, Slovakia and Sweden, while three tax bands were applied in Austria, Denmark, Greece and Great Britain. Amongst these countries, the ratio of income at which top rate is in force to an average annual gross earnings ranged from 4.4 in Great Britain to only 0.9 in Ireland (i.e. the top rate is actually the basic rate applied to the majority of employees, another rate is reduced rate applied to low-income earners). The ratio mainly did not exceeded 2 : it was equal to 1.8 in Poland, 1.6 in Sweden,
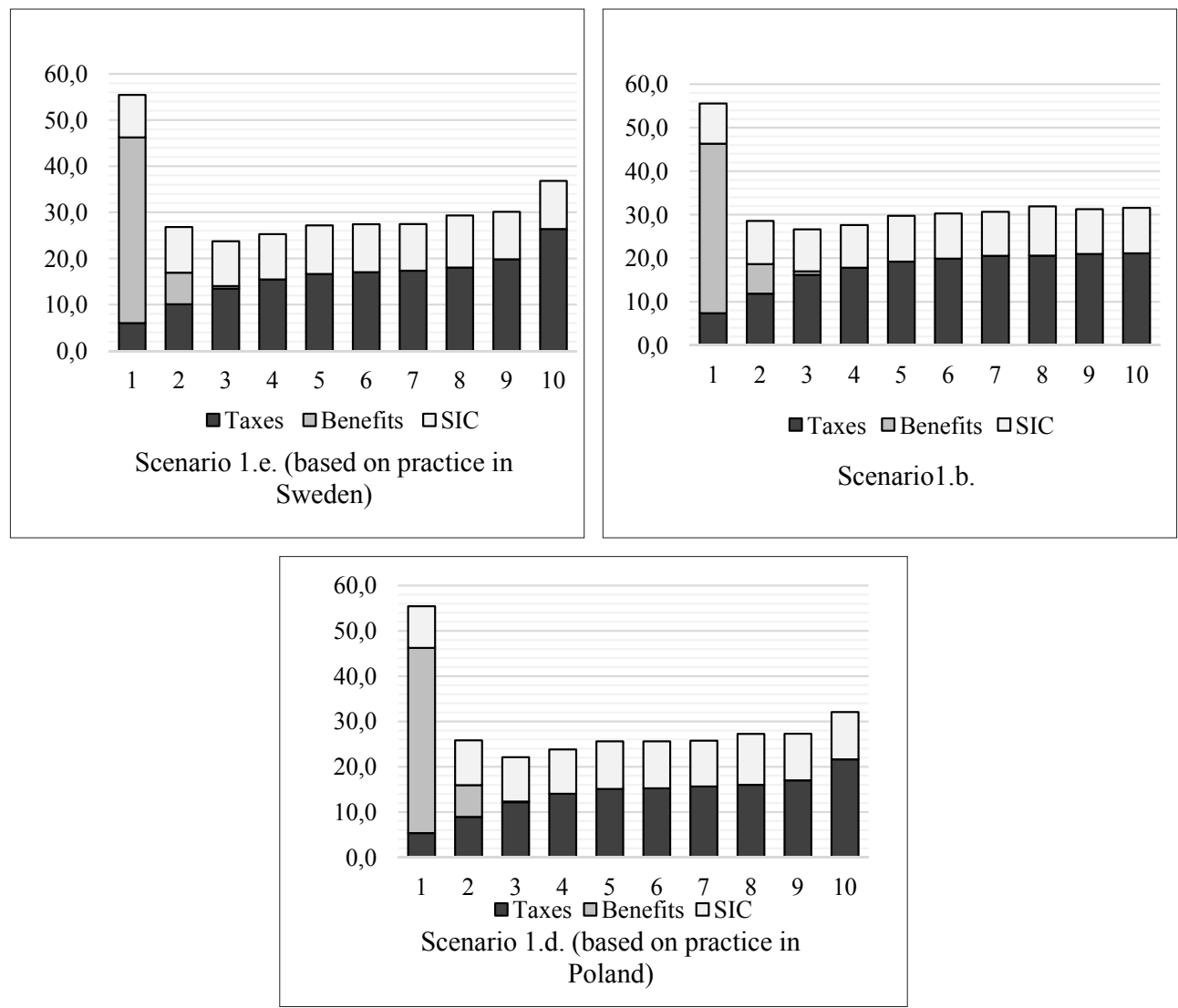

Fig. 3. Mean METRs and contribution of taxes, benefits and SICs by deciles of equivalised disposable income

Note: The tax system of 2014 that in force since January 2014 [1.b.] is used as a baseline in the analysis.

Source: authors' calculations based on EU-SILC 2010 data. 
2.1 in Austria and 1.5 in Netherlands (Eurostat, 2013 and author's calculations). The implemented reforms assessed for Latvia are the following:

- Monthly gross income in excess of EUR 1300 is taxed at $32 \%$. Income below that is taxed at $18 \%$. These tax rates were in force in Poland in 2013, while the choice of the income level at the top rate is also determined by the Polish practice: it is approximately 1.8 times higher than average monthly gross earnings in Latvia in 2013 of EUR 716 (Central Statistical Bureau of Latvia, 2014) [1.d.].

- Monthly gross income in excess of EUR 1150 is taxed at $40 \%$. Income below that is taxed at $20 \%$. These tax rates are in force in Sweden in 2013, and the income level at the top rate of EUR 1150 is 1.6 higher than average gross earnings in Latvia in 2013 and corresponds to the Swedish corresponding ratio [1.e.].

In both scenarios ([1.e.], and [1.d.]) of making PIT rate progressive, a higher tax rate for high income recipients is introduced, while the standard tax rate is reduced. Mean METR in the lowest decile is virtually not affected by the reduced standard rate as for them the PIT allowances accounts for a bigger share of income, while METRs in the middle deciles go down, as the standard tax rate is reduced. METR in the top decile goes up as a result of an increase in the PIT faced by high income earners. As a standard rate in [1.d.] scenario (i.e. $18 \%$ ) is lower than in [1.e.] scenario (i.e. $20 \%$ ), the decrease in the mean METRs in the middle deciles is larger in [1.d.] scenario.

\section{Progressive Personal Income Tax Allowance}

In 2013, the Ministry of Finance of Latvia announced about intention to develop a proposal of implementation progressive PIT allowance: maximum tax allowance is EUR 120 (LVL 84) per month for incomes below EUR 320 (LVL 225) per month ([2.a.], see Fig. 4). This cut-off value for income of EUR 320 corresponds to the statutory minimum wage of 2014 . Above the income up to the EUR 570 (LVL 400), the basic tax allowance tapers off at the rate of 0.22 (i.e., for every euro of income earned above the threshold, the tax allowance is reduced by 0.22 euro). For incomes above EUR 570 (LVL 400) the basic tax allowance is EUR 64 (LVL 45) (Latvijas Vēstneša portals, 2013). This income is markedly below the average gross income level in Latvia of EUR 716 monthly (Central Statistical Bureau of Latvia, 2014).

Another alternative reform of PIT allowances [2.b.] (Fig. 4) is similar to reform [2.a.], i.e. PIT allowance is gradually reduced taking into account the level of the income of the individual, while no basic allowance is granted to employees earning more than certain amount per month. Maximum tax allowance is EUR 120 (LVL 84) per month for incomes below EUR 320 (LVL 225) per month. Above the income up to the EUR 570 (LVL 400), the basic tax allowance tapers off at the rate of 0.22 (i.e., for every euro of income earned above the threshold, the tax allowance is reduced by 0.22 euro) until PIT allowance becomes zero, i.e. is basic allowance is not applied if annual income exceeds EUR 850 per month.

In the [2.c.] (Fig. 4) scenario, maximum tax allowance is higher and is tapered off quicker: non-taxable minimum 
is EUR 320 (LVL 225) per month for incomes below EUR 320 (LVL 225) per month. That means that earnings equal or below statutory minimum wage are not taxed by PIT. Above that level of income, the personal income allowance is gradually reduced at the rate 0.6 (i.e., for every euro of income earned above the threshold, the tax allowance is reduced by 0.60 euro). At the monthly gross income of EUR 850 personal allowance becomes zero.

In the [2.d.] scenario, PIT allowance currently implemented in Lithuania is proposed. Since 2009, in Lithuania the tax-exempt amount declines as income increasing. Maximum PIT allowance is LTL 5640 per year (EUR 16331 per year, EUR 136 per month) for the income
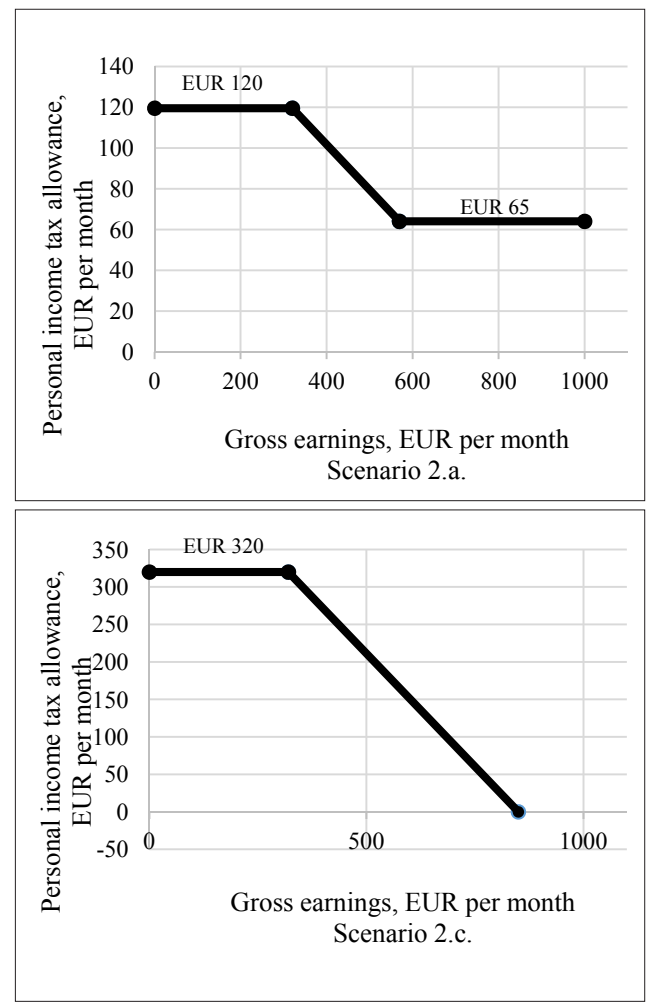

below LTL 9600 per year (EUR 2780 per year, EUR 232 per month). Above that income, the PIT allowance is gradually reduced at the rate of 0.20 (i.e., for every euro of income earned above the threshold, the non-taxable minimum is reduced by 0.20 euro). At the monthly gross income of LTL 3150 (EUR 910) PIT allowance is not applied.

Proposed reforms of the PIT allowance (see Fig. 5) does not virtually affect mean METR of the lowest deciles. The reason for it is that proposed reforms increase net income that results in reduction of meanstested benefits. For example [2.c.] reform shows that the mean METR of the lowest decile consists only of the contribution of benefits and SIC, i.e. $54.9 \%$ of additional
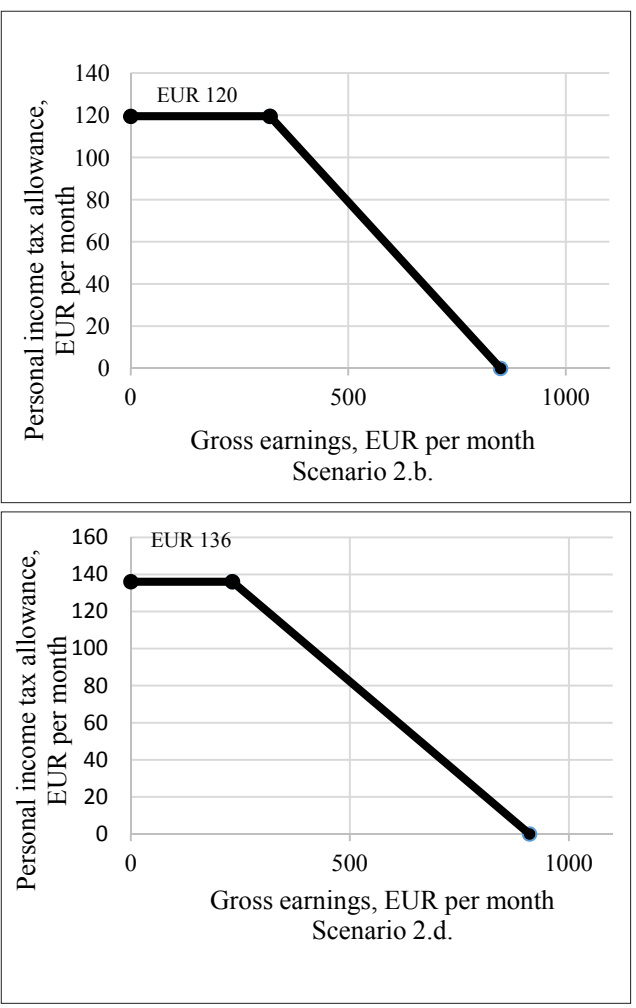

Fig. 4. Personal income tax allowance at different level of gross earnings, EUR per month 
income would be taxed away because of SIC and benefit withdrawal, but not because of taxes due to high level of basic allowance of EUR 320. This proves the fact that decrease of mean METR of the lowest decile and increase of their work incentives can be achieved only accompanied by reforms in means-tested benefits. However, in all scenarios the increase of the maximum basic allowance results in decrease of mean METRs in the middle deciles. Overall, the largest work incentives measured by mean METRs are observed in the tax system [2.c.].
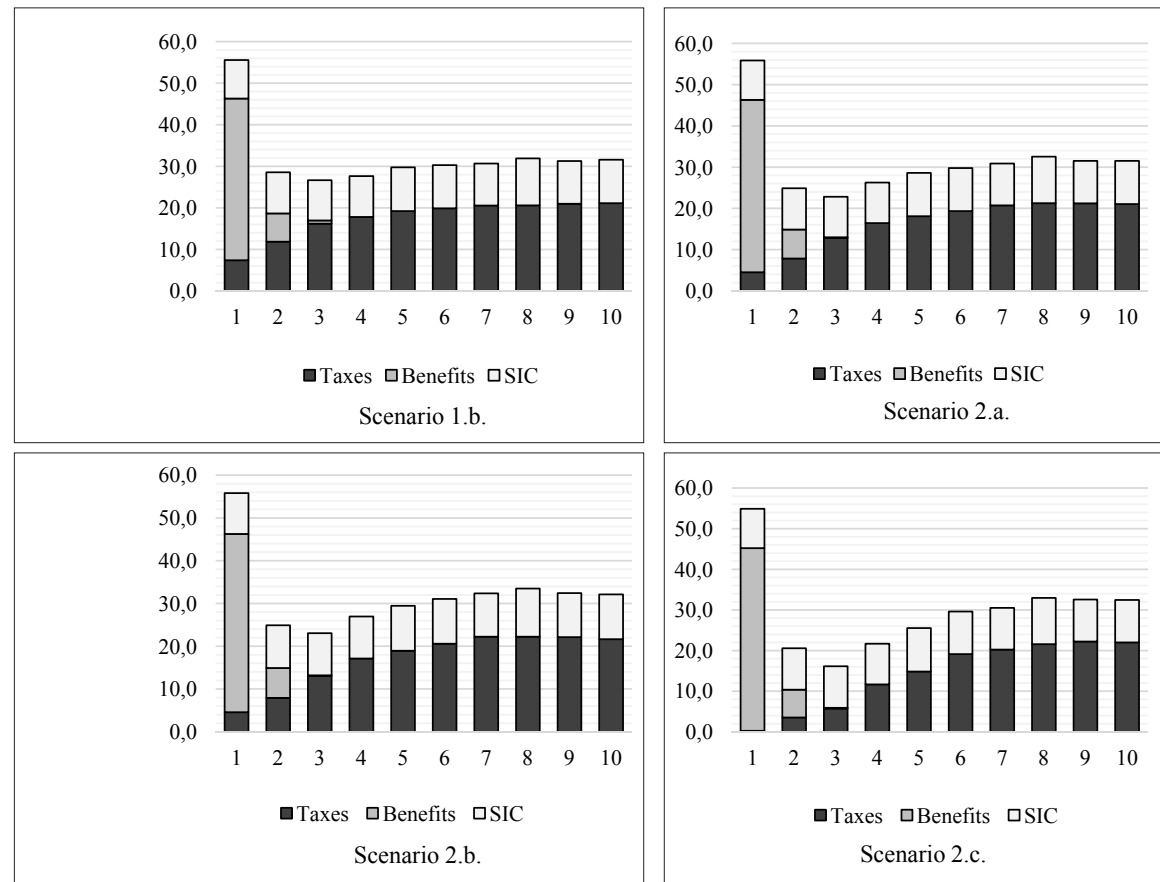

ario 2.b.

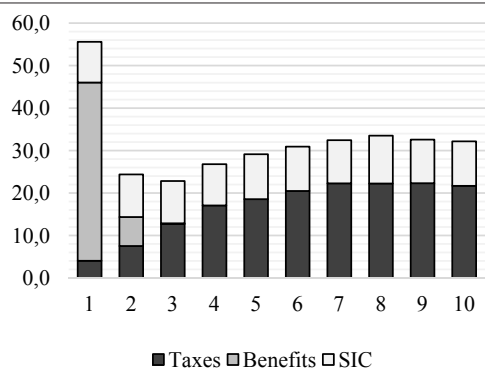

Scenario 2.d.

Fig. 5. Mean METRs and contribution of taxes, benefits and SICs by deciles of equivalised disposable income

Note: The tax system of 2014 that in force since January 2014 [1.b.] is used as a baseline in the analysis.

Source: authors' calculations based on EU-SILC 2010 data. 
The Impact of the Tax Reforms on Work Incentives of the whole Population

According to the values of the average METRs the highest work incentives are observed under the reform making PIT rates progressive based on the practice in Poland [1.d.]. All of the reforms that make the basic tax allowance progressive (reforms from [2.a.] to [2.d.]) reduce the average METR (see Fig. 6.), while the lowest mean METR is achieved under the reform that makes all minimum wage non-taxable [2.c.], followed by the reform proposed by the Ministry of Finance of Latvia [2.a.].

\section{The Impact of the PIT Rate and Basic Allowance Reforms on Revenues from PIT}

Fig. 7 presents the simulated impact of the reforms on revenues from PIT presented relative to the baseline 2014 system. In terms of the impact on revenues from PIT, the estimated impact of the reforms ranges from negative of $3.1 \%$ (reform [1.e.]) to negative of $35.6 \%$ (reform [1.c.]). The largest decrease of the revenues from PIT by $35.6 \%$ is caused by the decrease of flat PIT rate from $24 \%$ to $22 \%$ [1.c.], while the progressive PIT system based on the practice of Sweden caused the decrease of revenues from PIT only by $3.1 \%$ [1.e.].

The reform of making PIT rate progressive based on practice of Poland reduces revenues from PIT by $7.9 \%$ [1.d.], that is less loss making than that based on practice in Poland (decrease of revenues from PIT by $35.6 \%$ ).

The reforms of PIT allowance ([2.a.], [2.b.], and [2.c.]) result in decrease of revenues from PIT approximately equally by $4 \%-8 \%$, while the reform of making all minimum wage non-taxable decreased revenues from PIT by $21.7 \%$. The tax reform proposed by Ministry of Finance of Latvia [2.a.] results in lower revenues from PIT than tax system [2.b.], where the basic allowance is not applied to the highincome earners, by 3.8 percentage points (see Fig. 7), although it is overall less effecting in increasing work incentives (see Fig. 6).

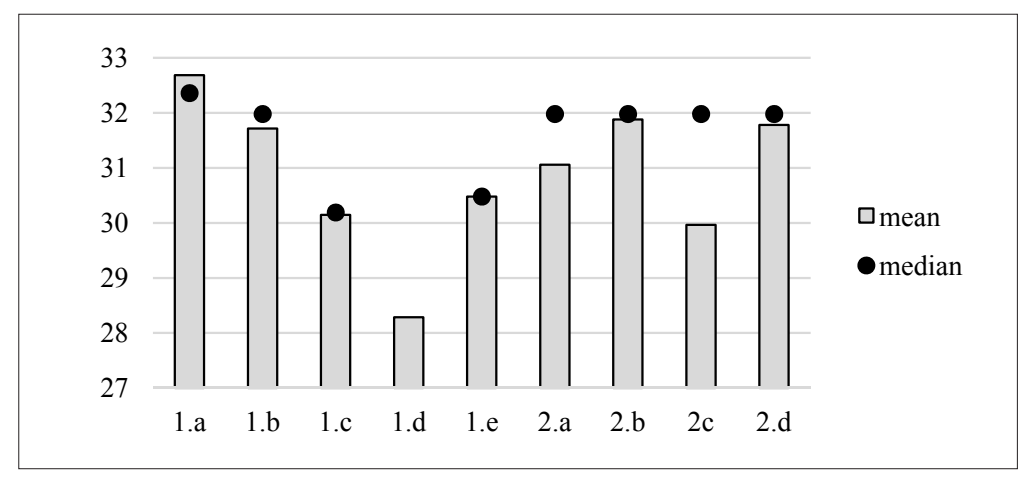

Fig. 6. Means and median METRs

Note: The tax system of 2014 that in force since January 2014 [1.b.] is used as a baseline in the analysis.

Source: authors' calculations based on EU-SILC 2010 data. 


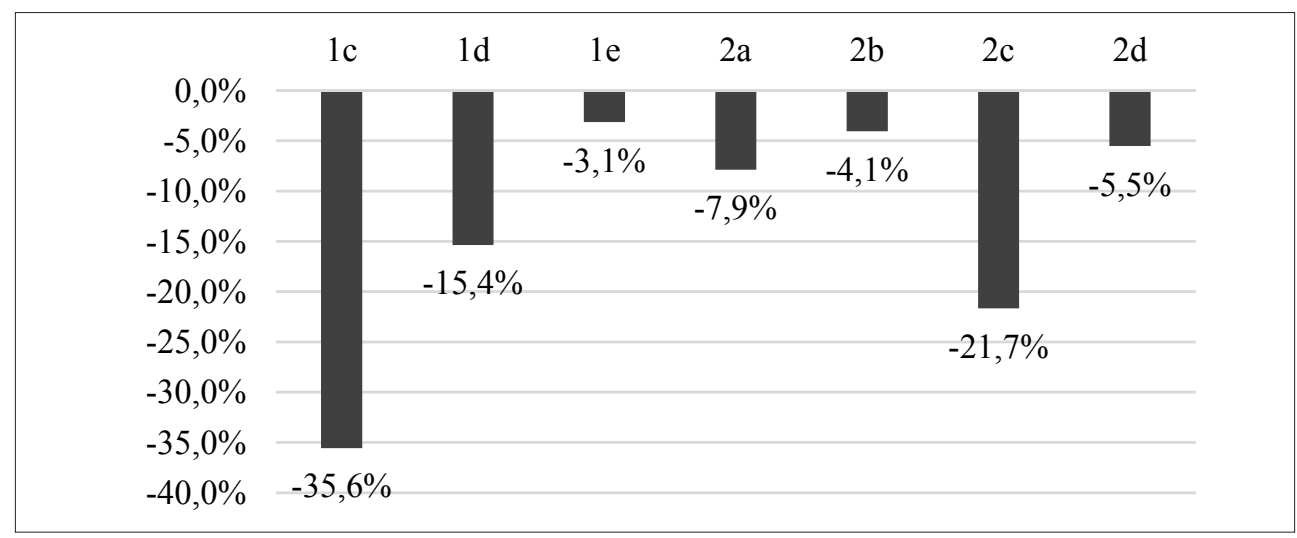

Fig. 7. Impact on revenues from PIT, \% from the baseline 2014 system

Source: authors' calculations based on based on EU-SILC 2010 data.

To conclude, the reform of making PIT system progressive can be more effective than making basic allowance progressive under certain conditions. Thus, the progressive PIT system [1.e.] based on the practice in Sweden results in slightly lower mean METR for all population (see Fig. 6: $30.5)$, than in case of application progressive basic allowance [2.a.] proposed by the Ministry of Finance of Latvia (see Fig. 6: 31.1). In addition, simulated impact of the reforms on revenues from PIT (see Fig. 7) shows that [1.e.] progressive PIT system is less detrimental than scenario [2.a.].

\section{Conclusions}

The paper results allow making conclusions about the effects of change of PIT rates and PITTING allowance on the work incentives of Latvia's population and to determine the socioeconomic reforms needed to increase work incentives in the country. The results of the paper can be used in the design of public policies:

1) The tax reform implemented since 2014 has a relatively weak impact on the work incentives of Latvians. Main gainers of the increased PIT allowances are those with low incomes (i.e. four lowest deciles), as for them the PIT allowances accounts for a bigger share of income, while METRs of higher income earners stayed virtually unaffected by the change in the tax system.

2) The gain from a reduced PIT rate is larger for those with higher incomes, and is smaller for those with low incomes, as for them the basic tax allowance accounts for a bigger share of income.

3) Author assesses the scenario of the tax system including a higher tax rate for high income recipients, while the standard tax rate is reduced. The reduced standard rate does not significantly affect the work incentives of those in the lowest decile, as for them the PIT allowances account for a bigger share of income, while METRs in the middle deciles go down, as the standard tax rate is reduced. METR in the top decile goes up as a result of an increase in the PIT faced by high income earners. 
4) The most effective reform of PIT rate in terms of increased work incentives of whole population (i.e. the lowest mean METR) is that based on the practice of Poland. This explained by the lower standard rate introduced (i.e. $18 \%$ ) than in other scenario (i.e. $20 \%$ ), the causes larger decrease in the mean METRs in the middle deciles.

5) A proposed reform of the PIT allowance does not virtually affect mean METR of the lowest deciles, due to increase of net income, which results in reduction of means-tested benefits. However, in all scenarios the increase of the maximum basic allowance results in decrease of mean METRs in the middle deciles, while mean METRs of the high-income recipients is actually not affected as for them the PIT allowances applied in the baseline scenario account for a bigger share of income.

6) The reform of making all minimum wage non-taxable decreased revenues from PIT relative to 2014 system by $21.7 \%$., although it is the most effective reform of basic allowance in terms of increased work incentives of whole population.

7) Another affective reform is proposed by the Ministry of the Finance of Latvia in 2013 that is less loss making and results in decrease of revenues from PIT only by $3.1 \%$.

8) Assessed impact of the tax reforms on work incentives shows, that decrease of mean METR of the lowest decile and increase of their work incentives can be achieved mainly accompanied by reforms in means-tested benefits.

9) The largest decrease of the revenues from PIT by $35.6 \%$ is caused by the decrease of flat PIT rate from $24 \%$ to $22 \%$, while the progressive PIT system based on the practice of Sweden caused the decrease of revenues from PIT only by $3.1 \%$. The reform of PIT rate based on practice of Poland reduces revenues from PIT by $7.9 \%$.

10) The progressive PIT system based on the practice in Sweden results in slightly lower mean METR for all population, than in case of application progressive basic allowance proposed by the Ministry of Finance of Latvia, as well as it is less detrimental than scenario with proposed progressive basic allowance.

\section{Proposals and Recommendations}

Proposal to the Ministry of Finance of Latvia: to develop a proposal of possible PIT rate progressive system, as it can be more effective than making basic allowance progressive in terms of revenues from PIT and changes in work incentives under certain conditions.

Proposal to Ministry of Welfare of Latvia: to develop a proposal of the reform of means-tested benefits that insured withdrawal of benefits rate in more gradual manner as an individual's income raises that could result in higher work incentive of low-income earners.

\section{Notes}

${ }^{1}$ Pegged to EUR; EUR=LTL 3.45280. 


\section{References}

1. Adam, S., Brewer, M., Shephard, A. (2006). The Poverty Trade-off. Work Incentives and Income Redistribution in Britain. - Institute for Fiscal Studies.

2. Berger, F., Islam, N., Liégeois, P. (2010). Discrete Choice Modelling of Labour Supply in Luxembourg Through EUROMOD Microsimulation // EUROMOD Working Paper No. EM5/10, pp. 1-36.

3. Central Statistical Bureau of Latvia (2014). Galvenie rādītāji. Internet access: <www.csb.gov.lv>, [accessed February 5, 2014].

4. Eurostat (2013). 'Taxes in Europe - Tax Reforms" Database (TEDB/TAXREF). Internet access: http://ec.europa.eu/taxation_customs/taxation/gen_info/info_docs/tax_inventory/index_ en.htm>, [accessed November 1, 2013].

5. Jara X., Tumino A. (2013). Tax-benefit Systems, Income Distribution and Work Incentives in the European Union // EUROMOD Working Papers EM7/13, EUROMOD at the Institute for Social and Economic Research.
6. Latvijas Vēstneša portāls (2013). Nodokḷos no 2014.gada plāno ieviest progresivitātes elementu. Internet access: <http://www.lvportals.lv/print php?id=256013>, [accessed January 10, 2014].

7. Ministry of Finance of Latvia ( 2013). Piedāvā alternatīvu priekslikumu darbaspēka nodokḷ reformai. Internet access: <http://www.fm.gov.lv/ lv/aktualitates/jaunumi/budzets/46842-piedavaalternativu-priekslikumu-darbaspeka-nodoklureformai>, [accessed December 5, 2013].

8. Sutherland H., Figari F. (2013). EUROMOD: the European Union Tax-Benefit Microsimulation Model // International Journal of Microsimulation. No. 6(1) 4-26, pp. 1-23.

9. University of Essex (2014). EUROMOD: TaxBenefit Microsimulation Model for the European Union. Internet access: <https://www.iser.essex. ac.uk/euromod>, [accessed January 4, 2014].

The paper submitted: May 10, 2014

Prepared for publication: June 1, 2014

\section{Anna ŽDANOVIČA}

\section{SOCIALINIU IR EKONOMINIU REFORMU POVEIKIS DARBO PASKATOMS LATVIJOJE}

\section{S a n t r a u k a}

2013 metais Latvijos Finansų ministerija pasiūlè keletą fizinių asmenų pajamų mokesčio reformų, įskaitant padidejusio gyventojų pajamų mokesčių lengvatas ir sumažintus socialinio draudimo immokų tarifus, kurie issigaliojo nuo 2014 sausio. Be to, 2014-aisiais ministerija turètų parengti pasiūlymą dèl progresyvaus neapmokestinamo minimumo. Kitas galimas progresyvinio mokesčio igyvendinimo scenarijus yra aukštesnio pajamų mokesčio dydžio taikymas skirtinguose pajamų lygiuose. Naudojant Europos Sąungos parengtą mokesčių ir socialinių išmokų mikrosimuliacinị modelị (EUROMOD), ir Europos Sajungos statistikos apie pajamas ir gyvenimo sąlygas (ES-SPGS) tyrimo mikro duomenis, šiame straipsnyje parodoma, koks yra siūlomų ir alternatyvių socialinių ir ekonominių reformų poveikis darbo paskatoms Latvijoje. Taikant ivvairius hipotetinius valstybès sprendimų scenarijus straipsnyje siekiama ivvertinti gyventojų pajamų mokesčio ir pagrindinių išmokų poveikį nustatant ribinę taikomų mokesčių normą (RTMN).
EUROMOD yra mokesčių ir socialinių išmokų skaičiavimo mikrosimuliacinis modelis sukurtas Europos Sąungos šalims, kuris leidžia apskaičiuoti ir palyginti mokesčių ir socialinių išmokų poveiki namų ùkių pajamoms ir darbo paskatoms kiekvie noje ES šalyje (University of Essex, 2014). Naudojant ši modelį, individų ir namų ūkių mokesčių ịsipareigojimai ir socialinès išmokos yra imituojami pagal esamas Latvijos politikos taisykles. Dažniausiai modelyje naudojami elementai yra GPM, socialinio draudimo įmokos, namų ūkio pašalpos, būsto pašalpos, socialinès pašalpos ir kitos su pajamomis susijusios išmokos.

Darbo paskatų analizė pagrinde paremta ribinès taikomų mokesčių normos (RTMN) duomenimis, kurie leidžia palyginti darbo paskatas, sukurtas Latvijos socialinių ir ekonominių reformų. RTMN yra skaičiuojamos padalinant visą gyventojų skaičių dešimtimis pagal ekvivalentinių disponuojamųjų pajamų pasiskirstymą, atsižvelgiant ị visus tarpusavio sąryšius tarp visų namų ūkių pajamų. 
Skaičiavimai pagrịsti ES-SPGS 2010 duomenimis (2009 metų pajamos). Duomenys nèra koreguoti pagal darbo rinkos ir demografinius pokyčius, kurie ìvyko per šį laikotarpị, todèl RTMN duomenys tarp skirtingų scenarijų atspindi mokesčių lengvatų sistemos pokyčius, kurie kontroliuoja RTMN pokyčius, kurie ịvyko dèl ekonominès situacijos ar gyventojų sudèties pasikeitimų.

Rezultatai rodo, kad nuo Latvijoje 2014 metu igyvendinama mokesčių reforma turi gana silpną poveikị latvių darbo paskatoms. Pradejjus taikyti progresinį GPM tarifą, kuris apimtų sumažintus standartinius mokesčių tarifus, darbo paskatos padidètų. Mokesčių reforma, kuria bazinè pašalpa buvo padaryta progresine, kaip tai pasiūlé
Finansų ministerija, nèra praktiškai igyvendinama ir neskatina visuc gyventojų darbingumo, o labiausiai įtakoja vidutines pajamas gaunančius asmenis.

Atsižvelgus ị rezultatus, autoré pradeda plètoti progresinio GPM tarifo sistemos pasiūlymą, nes jis gali būti veiksmingesnis nei dabar priimta progresinès bazinès pašalpos sistema, atsižvelgiant ị pajamas, gaunamas iš GPM ir darbo paskatų. Autore daro išvadą, kad turètų būti sukurta reforma, paremta vidutinès pašalpos dydžiu, kuris leistų kontroliuoti pašalpų išmokų dydžius atsižvelgiant ị materialinę naudą, gaunamą tuomet, kai individo pajamos kyla, kas labiau paskatintų dirbti mažas pajamas gaunančius asmenis. 